\title{
The Importance of Molecular Diagnostics and Screening Programs in Monitoring and Evaluation of Colorectal Cancer in the Republic of North Macedonia
}

\section{Značaj molekularne dijagnostike i screening programa u praćenju i evaluaciji kolorektalnog karcinoma u Republici Sjevernoj Makedoniji}

\author{
Trpkovska Jovanka', Velickova Nevenka² \\ 'Graduate Nurse, Institute of Public Health of the Republic of North Macedonia, Republic of North Macedonia \\ ${ }^{2}$ Associate Professor, University of Goce Delcev Stip, Faculty of Medical Sciences, Republic of North Macedonia; e-mail: nevenka.velickova@ugd.edu.mk
}

\section{Abstract}

Colorectal cancer (CRC) is one of the most common malignant diseases (12\% of the total) that occurs with an incidence of $15-30$ new cases per 100,000 population per year in European Union countries. The risk of this disease during life depends on many factors such as age, diet, physical activity, personal and family predisposition. Several preventive measures can reduce the number of colorectal cancer patients. First of all, the regular screening which allows the detection of precancerous polyps or cancer in the early stage and their successful surgical removal.

The purpose of this paper is to highlight the importance of screening programs as a preventive measure for the early detection of colorectal cancer and to reduce the morbidity and mortality of this disease. The strategy for improving the early detection of colorectal cancer also implies availability of useful information about the importance of screening programs for everyone as well as educating health care staff about the program itself.

Number of newly registered colorectal cancer cases in 2009 in the Republic North Macedonia stands at 547 with a rate of 26.7 compared to 2018 with 839 newly registered cases with a rate of 40.4 which clearly indicates an increasing trend of colorectal cancer.

Multidisciplinary approach to early detection of colorectal cancer, continuity of Program funding and quality of services will lead to reduction of morbidity and mortality of this type of cancer.

Keywords: Colorectal cancer, prevention, therapy, screening programs

Running head: Colorectal cancer and preventive measures

\section{Sažetak}

Kolorektalni karcinom (CRC) jedna je od najčešćih zloćudnih bolesti (ukupno 12 \%) koja se javlja s incidencijom od 15 do 30 novih slučajeva na 100000 stanovnika godišnje u zemljama Europske unije. Rizik za nastanak ove bolesti tijekom života ovisi o mnogim čimbenicima kao što su dob, prehrana, tjelesna aktivnost, osobna i genetska predispozicija. Postoji niz preventivnih mjera kojima se može smanjiti broj oboljelih od karcinoma debelog crijeva. Navedeno je moguće obavljanjem redovitog pregleda koji omogućuje otkrivanje prekanceroznih polipa ili raka u ranoj fazi te njihovo uspješno kirurško uklanjanje.

Svrha je ovog rada istaknuti važnost screening programa kao preventivne mjere za rano otkrivanje kolorektalnog karcinoma te smanjenje morbiditeta i smrtnosti uzrokovane ovom bolešću. Strategija za poboljšanje ranog otkrivanja karcinoma debelog crijeva također podrazumijeva bolje informiranje stanovništva 0 važnosti probirnih programa, kao i edukaciju zdravstvenog osoblja 0 samom programu.

Broj novoregistriranih slučajeva karcinoma debelog crijeva u 2009. godini u Republici Sjevernoj Makedoniji iznosi 547 sa stopom od 26,7 u usporedbi s 2018. godinom s 839 novoregistriranih slučajeva sa stopom od 40,4 što jasno ukazuje na trend rasta kolorektalnog karcinoma.

Multidisciplinarni pristup ranom otkrivanju raka debelog crijeva, kontinuitet financiranja Programa te kvaliteta zdravstvenih usluga dovest će do smanjenja morbiditeta i smrtnosti ove vrste karcinoma.

Ključne riječi: Prevencija, kolorektalni karcinom, terapija, probir

Kratak naslov: Kolorektalni karcinom i metode prevencije

Autor za korespondenciju/Corresponding author: Jovanka Trpkovska, Institute of Public Health of the Republic of North Macedonia, Republic of North Macedonia; Tel: +38978263673; e-mail: jovanka.trpkovska@gmail.com

\section{Introduction}

Colorectal cancer is one of the most common malignant diseases ( $12 \%$ of the total) with an incidence of $15-30$ new cases per 100,000 population per year. The risk of this disease during life depends on many factors such as age, diet, physical activity, personal and family predisposition. It is equally prevalent in both the male and female population, with the risk being much higher among smokers than nonsmokers because the risk of developing colon polyps is much higher and most often results in colorectal cancer [1]. Some preventive measures can reduce the number of colorectal cancer patients. First of all, there is regular screening that allows the detection of precancerous polyps or cancer in the early stage and their successful surgical removal. People at average risk of colorectal cancer, or those 
with no family history of the disease, are advised to begin regular screening at age of 50 . Screening at an earlier age is recommended for all those at higher risk of developing colorectal cancer. These are people with a family history of the disease or people with suspected or confirmed inherited colorectal cancer syndrome [2].

The stage of colorectal cancer indicates the extent of cancer and it is determined by two components: the local extent, i.e. the degree of penetration in depth through the layers of the intestinal wall, the spread through the regional lymph nodes as well.

End-stage diagnosis of colorectal cancer can only be performed after surgery and histopathological analysis of the operative material. The stage of the disease is the most important prognostic factor in determining the disease recurrence and survival after curative surgery $[3,4]$.

In the diagnostics of colorectal cancer, CEA (carcinoembryonic antigen) tumor markers are commonly used. Their elevated values and previous clinical picture of the patient, as well as deviation from other laboratory findings of normal reference values, confirm colorectal cancer. The values of CEA tumor markers are important parameters not only in the diagnostic process but also in the subsequent treatment and treatment process. In healthy adult males and females, the value of CEA tumor markers is $<2.5 \mu \mathrm{g} / \mathrm{L}$, while in smokers up to $5 \mu \mathrm{g} / \mathrm{L}$. The following tests and methods are used to diagnose CRC diagnoses: occult (invisible) drainage test, digital rectal examination, irigography, colonoscopy, flexible sigmoidoscopy, and virtual colonoscopy. The treatment of colorectal cancer depends on the stage of the disease. The three primary therapeutic options are: surgery, chemotherapy, and radiation $[5,6,7]$.

The purpose of this paper is to highlight the importance of screening programs as a preventive measure for the early detection of colorectal cancer and to reduce the morbidity and mortality of this disease. The strategy for improving the early detection of colorectal cancer also implies better information about the importance of screening programs for the population, as well as educating health care staff about the program itself [8].

\section{Materials and methods}

The Colorectal Cancer Prevention Program in the Republic of North Macedonia includes evidence and recommendations from the good clinical practice of international associations and working groups for the prevention, early detection, and treatment of colorectal cancer. The program is coordinated by the Health Development Strategy and the provisions of the Declaration: Europe against Colorectal Cancer, and also within the framework of the Resolution on the Prevention and Control of Cancer, adopted by the World Health Organization in 2003 in Geneva. The objective of the Program for Early Detection of Colorectal Cancer in the Republic of North Macedonia is reducing mortality by $15 \%$ over 5 years and covering $75 \%$ of the population at risk by 2015. The data and the Program for Prevention of Colorectal Cancer in the Republic of North Macedonia are evaluated by the Institute of Public Health of the Republic of North Macedonia in Skopje. A public health approach and media support for the importance of prevention and early detection of colorectal cancer for the measures covered by the program are required prior to the Prevention of Colorectal Cancer Prevention Program in North Macedonia.

The screening recommendation applies to the population at average risk and those without specific symptoms. The screening is performed with a Fecal Occult Blood Test (FOBT) in persons at risk factors, aged 50 to 74, in order to timely detect the first symptoms expressed by stool bleeding. Ministry of Health of the Republic of North Macedonia procures FOB tests and distributes them to the Public Health Centers. The Centers for Public Health submit the tests to their GPs in their area.

Primary care physicians inform their patients about the screening opportunity and advise them to do 3 consecutive FOB tests. The patients are given the tests by the general practitioner, and after taking the sample for analysis, the patient takes them to the Public Health Center. The Coordinator of the screening is the Institute of Public Health of the Republic of North Macedonia. The Public Health Centers are responsible for coordinating the activities in their area.

Preparation of information - educational materials and media campaign for colorectal cancer screening, implemented by the Institute of Public Health of the Republic of North Macedonia in cooperation with the NGO sector are very important in order to successfully inform the population about the need for this kind of examination. Monitoring and evaluation are carried out by the Institute of Public Health of the Republic of North Macedonia based on its database for organized screening and preparation of periodic reports as a summary of the reports from the Centers for Public Health. The Institute of Public Health of the Republic of North Macedonia evaluates all screening activities and reports, based on clearly defined performance indicators $[4,5]$.

\section{Results}

In Table [Table 1], we represented the rate of newly registered cases of colorectal cancer in the Republic of North Macedonia.

TABLE [1] number and rate of recovery collective cancer cases (c18-c21) in North Macedonia in the period 2009- 2018

\begin{tabular}{lcc}
\hline Year & Number & rate/100000 inhabitans \\
\hline 2009 & 547 & 26.7 \\
\hline 2010 & 503 & 24.5 \\
\hline 2011 & 628 & 30.5 \\
\hline 2012 & 507 & 24.6 \\
\hline 2013 & 652 & 31.6 \\
\hline 2014 & 818 & 39.5 \\
\hline 2015 & 859 & 41.5 \\
\hline 2016 & 776 & 37.4 \\
\hline 2017 & 832 & 40.1 \\
\hline 2018 & 839 & 40.4 \\
\hline
\end{tabular}

Source: Institute of Public Health of the Republic of North Macedonia - Skopje 
A number of newly registered cases of colorectal cancer in the Republic of North Macedonia in 2009 was 547 with a rate of 26.7, compared to 2018 with 839 newly registered cases with a rate of 40.4 , where there is an evident trend of increase in colorectal cancer, as represented at the table 2 [Figure 1].

The Screening Program indicates that changes of lifestyle and diet dramatically reduce the risk of CRC by as much as $60-80 \%$ [7].

\section{Discussion and Conclusion}

Colorectal cancer occurs in both the male and female population, most commonly in people over 50 years of age. Most of these neoplasms progress from normal mucosa to invasive carcinoma through the adenomatous polyp stage, so the prognosis for the patient is strongly related to the progression of the disease at the time of diagnosis. Symptoms usually occur in advanced age, when the prognosis is usually poor, which gives grounds for mass screening of the population. Therefore, a public health approach is needed by disseminating information through a media campaign, highlighting the importance of prevention and early detection of colorectal cancer $[9,10]$. The implementation of these activities requires more active involvement of the primary health care, the Public Health Centers and the Institute of Public Health, as well as all the secondary and tertiary health structures that are professionally related to this issue.

The multidisciplinary approach to the early detection of colorectal cancer, the continuity of Program funding and quality of services will lead to a reduction in the morbidity and mortality of this type of cancer [11].

\section{Authors declare no conflict of interest}

Nema sukoba interesa

\section{References}

[1] Ministry of Health of the Republic of Macedonia. Colorectal Cancer Screening Program in the Republic of Macedonia Macedonia in 2010. Available at: https://vlada.mk/node/17970?ln=en-gb/ https://www. iph.mk/en/links/
Rate of deaths from colorectal cancer C18-C21 by sex and age in the Republic of Northern Macedonia, 2009-2018

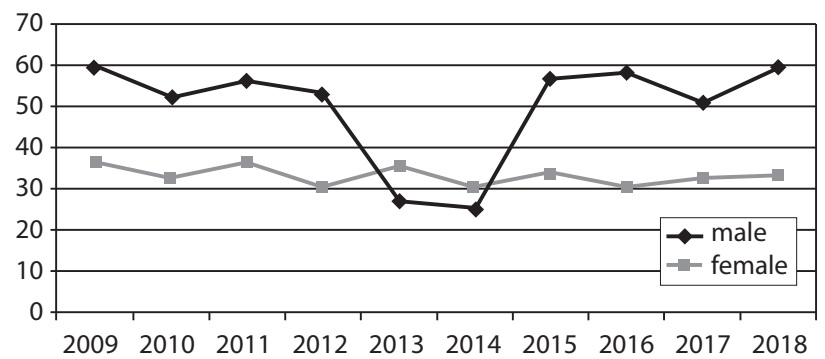

FiguRE [1] Rate of colorectal cancer deaths in the Republic of North Macedonia. Source: State Statistical Office of the Republic of North Macedonia - Skopje

[2] Ministry of Health of the Republic of Macedonia. Program for early Detection of Malignant Diseases in Republic of North Macedonia in 2018. Available at: https://vlada.mk/node/17970?ln=en-gb / https:// www.iph.mk/en/links/

[3] Krivokapić, Z., Barišić, G., Marković, V. Prevencija i rano otkrivanje, dijagnoza i tretman karcinoma debelog creva (Prevention, Early Detection, Diagnosis and Treatment of colorectal Cancer). Anali - srpska akademija nauka i umetnosti, ogranak u Novom Sadu. 2009; 5: 3646.

[4] WHO, National Cancer Control Programme. Policies and managerial guidelines, 2nd Edition, 2002.

[5] Republic Institute for Health Protection Skopje - Information on malignant neoplasms, IPH, Skopje, 2006.

[6] Cancer Registry in the Republic of North Macedonia, 2009-2018. Skopje, 2019.

[7] State Statistical Office of the Republic of North Macedonia Mortality lists, SSO, Skopje, 2009-2018. Available at: https://vlada.mk/ node/17970?In=en-gb / https://www.iph.mk/en/links/

[8] Stoitsovska-Lekovska T. Evaluation of data quality of thr Cancer Registry of the Republic of Macedonia and recommendations for improvement. Master tesis. Faculty of Medicine Skopje, 2006.

[9] Novak, M., Mauec, B., Zakotnik, J., Keršić, S., M, Metličar, J. Screening for colon and rectal cancer - SVIT program. Oncology 2013; 1: 21-5.

[10] NICE Clinical Guidelines 118 / Colonoscopic Surveillance for the Prevention of Colorectal Cancer in Persons with Ulcerative Colitis, Crohn's Disease or Adenomas, March 2011.

[11] Institute of Public Health of the Republic of North Macedonia / Flyer KRK - Be Informed, Protect Yourself From Bowel Cancer - Colorectal Cancer, 2019. Available at: https://vlada.mk/node/17970?ln=en-gb / https://www.iph.mk/en/links/ 